\title{
A Genetic Linkage Map including Loci for Male Sterility, Sugars, and Ascorbic Acid in Melon
}

\author{
Soon O. Park ${ }^{1}$, Hye Y. Hwang, and Kevin M. Crosby \\ Vegetable \& Fruit Improvement Center, Texas A\&M University, College Station, TX 77845; \\ Texas AgriLife Research and Extension Center, Texas A\&M System, Weslaco, TX 78596; and the \\ Department of Horticultural Sciences, Texas A\&M University, College Station, TX 77845
}

\begin{abstract}
AdDitional INDEX words. Cucumis melo, andromonoecious, randomly amplified polymorphic DNA markers, total soluble solids, sucrose, ratio of sucrose to total sugars

ABstract. Our objectives were to construct a randomly amplified polymorphic DNA (RAPD) marker-based linkage map using an $\mathrm{F}_{2}$ population derived from the melon (Cucumis melo) cross of 'Deltex' $\times$ TGR 1551, and map quantitative trait loci (QTL) for sucrose, total soluble solids (TSS), ratio of sucrose to total sugars (RSTS), and ascorbic acid as well as the $m s-3$ locus for male sterility previously reported in other muskmelon crosses. Due to the dominant character of RAPD markers, we scored 192 'Deltex'- and 158 TGR 1551-derived markers. One hundred eighty $(94 \%)$ of the 192 markers fit the expected 3:1 ratio. On the basis of the 180 markers, we constructed a 'Deltex' linkage map of 171 markers distributed on 12 linkage groups (LGs) with a total map distance of $1182 \mathrm{cM}$. One hundred fifty (95\%) of the 158 markers were identified to be nondistorted. We developed a TGR 1551 linkage map of 138 markers distributed on 12 LGs with a total distance of $1163 \mathrm{cM}$. A combined map of 12 LGs with a total map distance of $1394 \mathrm{cM}$ was made from 82 marker pairs expressing codominance. Nine LGs were integrated into those of the existing composite map by 17 anchor markers. We mapped the $m s-3$ locus for male sterility on LG 9, which corresponds to LG 10 of the classical map and LG VII of the composite map. Six QTL for sucrose were located on LGs 2, 3, 4, 6, and 11. Three on LGs 3, 4, and 6 and four on LGs 2, 3, 6, and 11 of the six QTL for sucrose were also noted to be QTL for TSS and RSTS, respectively. A single QTL for ascorbic acid was placed on LG 5 . This map will also be used to identify QTL for fruit sweetness, quality, size, and shape traits, as well as disease resistance.
\end{abstract}

Melon, an economically important horticultural crop grown in many temperate, subtropical, and tropical regions of the world (Wang et al., 1997), is a significant source of ascorbic acid, beta-carotene, folic acid, and potassium (Lester, 1997; Richter, 2000), as well as free sugars and water (Martyn and Miller, 1996). Low levels of calories, fat, and sodium are also present in melon fruit flesh (Lester, 1997). Two antioxidant compounds, ascorbic acid and beta-carotene, are important human bioactive nutrients (Adams and Richardson, 1981; Lester, 1997). Because consumers prefer sweet-tasting melons (Lester and Shellie, 1992), high soluble sugars (sucrose, fructose, and glucose) determine marketable grades (U.S. Government Printing Office, 1990). Therefore, improving sugar content is a significant goal in breeding programs worldwide (Sinclair et al., 2006).

Melon is a diploid species possessing 12 different chromosomes as a single set (Dane, 1991). Melon's genome is 4.5-5.0 $\times 10^{8}$ bp (Arumuganathan and Earle, 1991); genetic polymorphism ranges from $10 \%$ to $15 \%$ (Staub et al., 1997) and

Received for publication 9 May 2008. Accepted for publication 31 Oct. 2008. This research was funded in part by U.S. Department of Agriculture grants 2001-34402-10543, 2003-34402-13647, and 2004-34402-14768, "Designing Foods for Health." We acknowledge financial support from the South Texas Melon Committee.

We appreciate the constructive criticism of two internal reviewers, Drs. Erik Mirkov and John Jifon (Texas AgriLife Research and Extension Center) to improve the manuscript. We also appreciate an external reviewer, Dr. Gene E. Lester (U.S. Department of Agriculture-Agricultural Research Service at Weslaco). We thank technicians Hyun J. Kang and Kay Harding (Texas AgriLife Research and Extension Center) for their assistance.

${ }^{1}$ Corresponding author. E-mail: so-park@tamu.edu. genomic length is 2276 to $3250 \mathrm{cM}$ (Staub and Meglic, 1993). Pitrat (1991) developed a classical melon linkage map consisting of 28 vegetative, floral, and disease resistance markers distributed on eight linkage groups (LGs) and five unlinked loci. Two LGs, including 11 isozyme loci with a total distance of $98 \mathrm{cM}$, were constructed by Staub et al. (1998). Molecular melon linkage maps constructed on the basis of various types of genetic markers such as randomly amplified polymorphic DNA (RAPD), restriction fragment length polymorphism (RFLP), simple sequence repeat (SSR), amplified fragment length polymorphism (AFLP), and single nucleotide polymorphism (SNP) have been reported (Baudracco-Arnas and Pitrat, 1996; Danin-Poleg et al., 2000, 2002; Gonzalo et al., 2005; Oliver et al., 2001; Perin et al., 2002b; Silberstein et al., 2003; Wang et al., 1997; Zalapa et al., 2007). Attempts have been made to merge several C. melo linkage maps using SSR markers (Danin-Poleg et al., 2000; Gonzalo et al., 2005), however, due to different genetic markers and parental genotypes, mostly used in Europe and Asia, few common phenotypic or SSR markers were conserved among linkage maps (Danin-Poleg et al., 2001; Perin et al., 2002b). Thus, only a partially integrated melon linkage map is currently available (Perin et al., 2002b).

According to the 2006 melon gene list (Pitrat, 2005-2006), more than 160 qualitative genes have been identified. Molecular melon maps have been widely used to map quantitative trait loci (QTL) for total soluble solids (TSS; Monforte et al., 2004), fruit weight and shape (Monforte et al., 2004; Perin et al., 2002a), fruit and flesh color (Monforte et al., 2004), fruit ripening (Monforte et al., 2004; Perin et al., 2002c), ovary length and width (Perin et al., 2002a), and yield (Zalapa et al., 2007). Quantitative loci for resistance to viral (Baudracco-Arnas and 
Pitrat, 1996; Danin-Poleg et al., 2002) and fungal (BaudraccoArnas and Pitrat, 1996) diseases were also mapped. Therefore, molecular tagging and mapping information for these traits could prove useful to melon breeders using molecular markers for marker-assisted selection (MAS).

An $F_{2}$ population of a 'Deltex' $\times$ TGR 1551 cross segregated for economically important traits including sugars, ascorbic acid, fruit size and shape, flesh and seed cavity size, seed size and quantity, and viral and fungal disease resistance (Alvarez et al., 2005; Lopez-Sese and Gomez-Guillamon, 2000; Park et al., 2007a, 2007b, 2007c; Sinclair et al., 2006). Some of these traits are not mapped on published linkage maps (Pitrat, 20052006). Development of a molecular marker-based linkage map is an essential step in identifying locations of QTL that impact these unmapped traits. Park et al. (2004b) identified three RAPD and sequence characterized amplified region (SCAR) markers linked to the $m s-3$ locus for male sterility by means of bulked segregant analysis in an ms-3 $\times$ 'TAM Dulce' $\mathrm{F}_{2}$ population. Eleven RAPD and andromonoecious (a) markers associated with muskmelon QTL for sugars were detected (Sinclair et al., 2006). They also reported nine RAPD markers associated with QTL for ascorbic acid. These QTL for fruit quality traits were confirmed in different populations and environments before using molecular markers for MAS in breeding programs, as suggested by Park et al. (1999). Thus, our objectives were to construct a RAPD marker-based genetic linkage map using an $\mathrm{F}_{2}$ population of the 'Deltex' $\times$ TGR 1551 cross, and to place previously identified loci for male sterility, sucrose, TSS, ratio of sucrose to total sugars (RSTS), and ascorbic acid onto the map.

\section{Materials and Methods}

Plant materials. $F_{1}$ and $F_{2}$ generation progenies were derived from the 'Deltex' $\times$ TGR 1551 cross in a greenhouse at Texas AgriLife Research and Extension Center (TAREC) in Weslaco during Winter 2003. 'Deltex', a commercial ananas melon type [C. melo ssp. melo var. reticulatus with thin or scant net and white flesh (Pitrat et al., 2000)] with high fruit quality, was developed by Nunhems USA (Parma, ID). As the female parent, it provides resistance to Fusarium wilt caused by Fusarium oxysporum f. sp. melonis (races 0 and 2) and powdery mildew caused by Podosphaera xanthii (sect. Sphaerotheca) xanthii (race 1) (Jahn et al., 2002) (Table 1). TGR 1551 (PI 482420), an exotic melon originally obtained from Zimbabwe, is a wild type with low fruit quality. As the male parent, it provides resistance to powdery mildew (races 1 and 2) (Alvarez et al., 2005), downy mildew caused by Pseudoperonospora cubensis (S.O. Park and K.M. Crosby, unpublished data), and cucurbit yellow stunting disorder virus (CYSDV) (Lopez-Sese and Gomez-Guillamon, 2000).

One hundred eight $\mathrm{F}_{2}$ plants and the parents were planted in the greenhouse at TAREC on 15 Mar. 2003. Plants were grown in 11-L plastic containers (one plant per pot) containing soilless media (Sunshine Mix \#4; Sun Gro Horticulture, Bellevue, WA). Peters 20N-8.7P-16.6K water-soluble fertilizer (Scotts, Marysville, $\mathrm{OH}$ ) was applied weekly. Mean day/night greenhouse temperatures were $26 \pm 3 / 23 \pm 2{ }^{\circ} \mathrm{C}$. Day lengths ranged from 12 to $14 \mathrm{~h}$. Stamen presence or absence in female flowers was checked twice on all $\mathrm{F}_{2}$ and parent plants at different times during flowering.
Table 1. Comparison of major characteristics between the melon parents 'Deltex' and TGR 1551.

\begin{tabular}{|c|c|c|}
\hline Trait & 'Deltex' & TGR 1551 \\
\hline Fruit shape & Blocky round & Blocky oval \\
\hline Fruit color & Light green yellow & Gold \\
\hline Fruit net & Presence & Absence \\
\hline Andromonoecious $(a)$ & Andromonoecious & Monoecious \\
\hline Fruit weight $(\mathrm{g})^{\mathrm{z}}$ & 923 & 421 \\
\hline Fruit length (mm) & 142 & 108 \\
\hline Fruit diameter $(\mathrm{mm})$ & 115 & 87 \\
\hline Flesh color & Light yellow ivory & Ivory \\
\hline Flesh weight (g) & 783 & 401 \\
\hline Flesh diameter $(\mathrm{mm})$ & 61 & 38 \\
\hline Seed cavity weight (g) & 59 & 118 \\
\hline Seed cavity diameter $(\mathrm{mm})$ & 52 & 54 \\
\hline Seed quantity ${ }^{\mathrm{y}}$ & 187 & 316 \\
\hline Total seed weight (g) & 6.6 & 6.7 \\
\hline Single seed weight $(\mathrm{mg})$ & 35.4 & 21.0 \\
\hline Total soluble solids $(\%)^{\mathrm{x}}$ & 12.3 & 3.5 \\
\hline Total sugars $\left(\mathrm{mg} \cdot \mathrm{g}^{-1}\right)$ & 68.4 & 28.7 \\
\hline Sucrose $\left(\mathrm{mg} \cdot \mathrm{g}^{-1}\right)$ & 37.5 & 0.0 \\
\hline Glucose $\left(\mathrm{mg} \cdot \mathrm{g}^{-1}\right)$ & 12.6 & 14.4 \\
\hline Fructose $\left(\mathrm{mg} \cdot \mathrm{g}^{-1}\right)$ & 18.3 & 14.3 \\
\hline $\begin{array}{l}\text { Ratio of sucrose to } \\
\text { total sugars }\end{array}$ & 54.8 & 0.0 \\
\hline $\begin{array}{l}\text { Ratio of glucose to } \\
\text { total sugars }\end{array}$ & 18.4 & 50.2 \\
\hline $\begin{array}{l}\text { Ratio of fructose to } \\
\text { total sugars }\end{array}$ & 26.8 & 49.8 \\
\hline $\begin{array}{l}\text { Ascorbic acid } \\
\qquad(\mathrm{mg} / 100 \mathrm{~g})^{\mathrm{w}}\end{array}$ & 76.8 & $\begin{array}{l}\text { Below detectable } \\
\text { levels }\end{array}$ \\
\hline $\begin{array}{l}\text { Cucurbit yellow stunting } \\
\text { disorder virus }{ }^{\mathrm{v}}\end{array}$ & Susceptible & Resistant \\
\hline Fusarium wilt ${ }^{\mathrm{u}}$ & $\begin{array}{l}\text { Resistant } \\
\quad \text { (races } 0 \text { and 2) }\end{array}$ & Susceptible \\
\hline Powdery mildew ${ }^{t}$ & Resistant (race 1) & $\begin{array}{l}\text { Resistant } \\
\quad(\text { races } 1 \text { and } 2)\end{array}$ \\
\hline Downy mildew ${ }^{\mathrm{s}}$ & Susceptible & Resistant \\
\hline
\end{tabular}

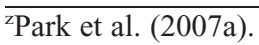

yPark et al. (2007b).

xPark et al. (2007c).

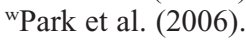

vLopez-Sese and Gomez-Guillamon (2000).

"Sinclair et al. (2006).

${ }^{t}$ Alvarez et al. (2005).

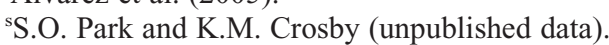

RAPD. Fully expanded leaves from the $108 \mathrm{~F}_{2}$ plants as well as from the parents were collected $21 \mathrm{~d}$ after planting. Total genomic DNA was extracted from the leaf tissue using the method of Skroch and Nienhuis (1995). A total of 372 random 10-mer primers (Operon Technologies, Alameda, CA) were used for the RAPD analysis (Williams et al., 1990). Polymerase chain reactions (PCR) were performed on 96-well plates in a thermal cycler (model PTC-0100; MJ Research, Waltham, MA). Protocols for PCR and the composition of the final volume of reactants were the same as those described by Skroch and Nienhuis (1995). A 100-bp DNA ladder (Life Technologies, Grand Island, NY) was used to estimate the length of RAPD markers. The name of each RAPD marker is derived from an "O" prefix for Operon primers, the letters identifying the Operon kit, Operon primer number, and the approximate length 
of the marker (Park et al., 2004a). The 363 primers were used to screen between the parents 'Deltex' and TGR 1551. Primers that generated marker polymorphisms between the parents were tested in the $\mathrm{F}_{2}$ population to score RAPD markers for use in developing linkage maps. We repeated these reactions at least three times in the population to verify RAPD markers.

To integrate our map into other published melon maps, we used genomic DNA of three parental genotypes provided by M. Pitrat (Institut National de la Recherche Agronomique, Montfavet, France). Fifteen primers were tested twice in the mapping population based on their PCR protocol and reaction conditions (Baudracco-Arnas and Pitrat, 1996; Oliver et al., 2001; Silberstein et al., 2003), along with each parental pair, to score a total of 15 published common RAPD markers. We used the original names of the 15 RAPD makers. Five primers were tested in the three genotypes to survey the presence or absence of six markers to determine if the remaining LGs could be joined into regions of the composite map (Perin et al., 2002b). We also tested an additional nine primers in our population based on the conditions of Park et al. (2004b) and Sinclair et al. (2006) to map previously identified QTL for fruit quality traits and the $m s-3$ locus on the map.

Linkage analysis. The chi-square test was used to test goodness-of-fit to a $3: 1$ present to absent ratio to detect segregation distortion of dominant markers or a $1: 2: 1$ ratio of nonsegregating for the 'Deltex' allele, segregating for the two alleles, and nonsegregating for the TGR 1551 allele to identify segregation distortion of codominant markers in the $F_{2}$ population. Because of the dominant character of RAPD markers, two linkage maps were separately constructed using 192 'Deltex'- or 158 TGR 1551-derived markers segregating in the $108 \mathrm{~F}_{2}$ plants of the 'Deltex' $\times$ TGR 1551 cross by MAPMAKER version 3.0 (Lander et al., 1987). On the basis of a logarithm of odds (LOD) score of 3.0 and a linkage threshold of 0.4 , LGs were displayed using the Group command. To establish an LG, a subset of markers was initially selected on the basis of LOD scores and pairwise linkages. The best linkage order within the subset was calculated using the Compare command and additional markers were then inserted using the Try command. LOD scores of at least 2.0 were considered different between the most and second most likely position for the marker. The Ripple command was finally used to control the marker order. Map distances between ordered loci of markers were calculated using recombination fractions and the Kosambi mapping function (Kosambi, 1944).

\section{Results and Discussion}

Marker polymorphisms. Amplified DNA fragments were generated from 'Deltex' and TGR 1551 by 370 of 387 primers. No amplified DNA fragments were produced by the remaining 17 primers, indicating that suitable target sequences were unavailable on the chromosomal regions. An average of 12.4 amplified DNA fragments ranging from 150 to $3000 \mathrm{bp}$ in length were generated per primer. A total of 455 RAPD markers were polymorphic between the parents using 207 primers with an average of 2.2 polymorphic DNA bands per primer. One hundred forty-seven primers displayed 242 amplified DNA fragments in 'Deltex' that were absent in TGR 1551. One hundred thirty-one primers generated 213 amplified DNA fragments in TGR 1551 that were absent in 'Deltex'. Of the
455 RAPD marker fragments, 349 segregated in the $F_{2}$ population, whereas 106 did not segregate or were nonscored. Thus, 349 RAPD markers ranging from 150 to $2400 \mathrm{bp}$ in length, 192 obtained from 'Deltex' and 157 obtained from TGR 1551 , were scored from the population using 178 primers.

'DelteX' LINKAGE MAP. A total of 137 primers generated the 192 'Deltex'-derived markers with an average of 1.4 markers per primer (Table 2). Of the 192 markers, 180 (94\%) fit the expected $3: 1$ ratio in the $F_{2}$ population. The remaining 12 markers $(6 \%)$, however, deviated significantly from the $3: 1$ ratio $(P<0.05)$. On the basis of the 180 'Deltex'-derived markers, we constructed a linkage map of 171 markers, along with nine unassigned markers (Fig. 1). This 'Deltex' linkage map consisted of 12 LGs with a total map distance of $1182 \mathrm{cM}$ (Table 2). The linkage map included 148 loci with an average distance of $8.0 \mathrm{cM}$ between loci. A single marker was observed at 126 different loci, while at least two cosegregating markers were found at 22 loci on nine LGs. The number of mapped markers per LG ranged from seven on LG 7D to 26 on LG 10D. An average of 14.3 markers was mapped per LG. The number of loci per LG varied from seven on LG 7D to 22 on LG 10D. An average of 12.3 loci was located per LG. Linkage group 5D was the shortest (39 cM) and LG 10D was the longest (192 cM). The average length of the LGs was $98.5 \mathrm{cM}$.

TGR 1551 LINKAGE MAP. The 157 TGR 1551-derived markers were produced by 113 primers with an average of 1.4 markers per primer (Table 2). Of 158 RAPD and $a$ markers, $150(95 \%)$ were identified to be nondistorted. In contrast, eight (5\%) proved to be distorted at $P<0.05$. Along with 12 unassigned markers, a linkage map of 138 RAPD and $a$ markers was developed based on the 150 nondistorted markers (Fig. 1). This map was composed of 12 LGs with a total map distance of $1163 \mathrm{cM}$ (Table 2). A total of 127 loci were contained in the map, with an average distance of $9.2 \mathrm{cM}$ between loci. A single marker was noted at 116 loci, while two cosegregating markers were observed at 11 loci. The number of loci per LG varied from four on LG 7T to 20 on LG 10T. An average of 10.6 loci was located per LG. The average LG length was $96.9 \mathrm{cM}$.

Various marker types such as isozyme (Baudracco-Arnas and Pitrat, 1996; Oliver et al., 2001; Staub et al., 1998), RFLP (Baudracco-Arnas and Pitrat, 1996; Gonzalo et al., 2005; Oliver et al., 2001; Perin et al., 2002b; Silberstein et al., 2003), SSR (Danin-Poleg et al., 2002; Gonzalo et al., 2005; Oliver et al., 2001; Perin et al., 2002b; Silberstein et al., 2003; Wang et al., 1997; Zalapa et al., 2007), AFLP (Oliver et al., 2001; Perin et al., 2002b; Silberstein et al., 2003; Wang et al., 1997; Zalapa et al., 2007), and SNP (Gonzalo et al., 2005) have been used in constructing melon linkage maps. Also, 6 to 114 RAPD markers were used for this purpose (Baudracco-Arnas and Pitrat, 1996; Danin-Poleg et al., 2002; Oliver et al., 2001; Perin et al., 2002b; Silberstein et al., 2003; Wang et al., 1997; Zalapa et al., 2007). This is the first report of 'Deltex' and TGR 1551 linkage maps derived from 349 dominant RAPD markers in an $\mathrm{F}_{2}$ population of melon.

Wang et al. (1997) observed 97 polymorphic RAPD markers between MR1 and 'Yokneam' using 551 primers showing a low marker polymorphism. Danin-Poleg et al. (2002) also reported a low RAPD marker polymorphism between PI 414723 and 'Dulce'. In contrast, we found 455 polymorphic RAPD markers between 'Deltex' and TGR 1551 using 387 primers, suggesting a high marker polymorphism. The high RAPD marker polymorphism noted here agrees with the findings of Baudracco- 
Table 2. Summary of a melon linkage map based on 350 'Deltex'- and TGR 1551-derived RAPD and andromonoecious ( $a$ ) markers segregating in $108 \mathrm{~F}_{2}$ plants from the 'Deltex' $\times$ TGR 1551 cross.

\begin{tabular}{|c|c|c|c|c|c|c|c|c|c|}
\hline $\begin{array}{l}\text { Linkage } \\
\text { group } \\
\text { pair } \\
\end{array}$ & $\begin{array}{l}\text { Parental } \\
\text { marker } \\
\text { source }\end{array}$ & $\begin{array}{c}\text { Total } \\
\text { markers } \\
\text { (no.) }\end{array}$ & $\begin{array}{c}\text { Distorted } \\
\text { markers } \\
(\text { no. })^{\mathrm{z}} \\
\end{array}$ & $\begin{array}{c}\text { Mapped } \\
\text { markers } \\
\text { (no.) }\end{array}$ & $\begin{array}{l}\text { Total } \\
\text { loci } \\
\text { (no.) } \\
\end{array}$ & $\begin{array}{c}\text { Cosegregating } \\
\text { marker loci } \\
\text { (no.) }\end{array}$ & $\begin{array}{c}\text { Single } \\
\text { marker loci } \\
\text { (no.) }\end{array}$ & $\begin{array}{c}\text { Map } \\
\text { distance } \\
(\mathrm{cM})\end{array}$ & $\begin{array}{c}\text { Mean } \\
\text { distance } \\
(\mathrm{cM}) \\
\end{array}$ \\
\hline \multirow[t]{3}{*}{1} & Deltex & 17 & 1 & 16 & 15 & 1 & 14 & 106 & 7.1 \\
\hline & TGR 1551 & 15 & 0 & 15 & 12 & 3 & 9 & 79 & 6.6 \\
\hline & Combined & 32 & 1 & 31 & 27 & 4 & 23 & 106 & 6.9 \\
\hline \multirow[t]{3}{*}{2} & Deltex & 14 & 1 & 13 & 12 & 1 & 11 & 93 & 7.7 \\
\hline & TGR 1551 & 9 & 2 & 7 & 7 & 0 & 7 & 75 & 10.7 \\
\hline & Combined & 23 & 3 & 20 & 19 & 1 & 18 & 93 & 8.8 \\
\hline \multirow[t]{3}{*}{3} & Deltex & 11 & 1 & 10 & 10 & 0 & 10 & 83 & 8.3 \\
\hline & TGR 1551 & 11 & 0 & 11 & 11 & 0 & 11 & 155 & 14.1 \\
\hline & Combined & 22 & 1 & 21 & 21 & 0 & 21 & 155 & 11.3 \\
\hline \multirow[t]{3}{*}{4} & Deltex & 12 & 1 & 11 & 11 & 0 & 11 & 161 & 14.6 \\
\hline & TGR 1551 & 7 & 0 & 7 & 7 & 0 & 7 & 106 & 15.1 \\
\hline & Combined & 19 & 1 & 18 & 18 & 0 & 18 & 161 & 14.8 \\
\hline \multirow[t]{3}{*}{5} & Deltex & 14 & 0 & 14 & 10 & 3 & 7 & 39 & 3.9 \\
\hline & TGR 1551 & 15 & 0 & 15 & 15 & 0 & 15 & 113 & 7.5 \\
\hline & Combined & 29 & 0 & 29 & 25 & 3 & 22 & 113 & 6.1 \\
\hline \multirow[t]{3}{*}{6} & Deltex & 17 & 1 & 16 & 12 & 4 & 8 & 71 & 5.9 \\
\hline & TGR 1551 & 15 & 0 & 15 & 13 & 2 & 11 & 110 & 8.5 \\
\hline & Combined & 32 & 1 & 31 & 25 & 6 & 19 & 110 & 7.2 \\
\hline \multirow[t]{3}{*}{7} & Deltex & 8 & 1 & 7 & 7 & 0 & 7 & 91 & 13.0 \\
\hline & TGR 1551 & 4 & 0 & 4 & 4 & 0 & 4 & 38 & 9.6 \\
\hline & Combined & 12 & 1 & 11 & 11 & 0 & 11 & 91 & 11.7 \\
\hline \multirow[t]{3}{*}{8} & Deltex & 22 & 1 & 21 & 17 & 4 & 13 & 130 & 7.6 \\
\hline & TGR 1551 & 13 & 2 & 11 & 10 & 1 & 9 & 110 & 11.0 \\
\hline & Combined & 35 & 3 & 32 & 27 & 5 & 22 & 130 & 8.9 \\
\hline \multirow[t]{3}{*}{9} & Deltex & 16 & 1 & 15 & 12 & 3 & 9 & 91 & 7.6 \\
\hline & TGR 1551 & 13 & 1 & 12 & 11 & 1 & 10 & 88 & 8.0 \\
\hline & Combined & 29 & 2 & 27 & 23 & 4 & 19 & 91 & 7.8 \\
\hline \multirow[t]{3}{*}{10} & Deltex & 28 & 2 & 26 & 22 & 4 & 18 & 192 & 8.7 \\
\hline & TGR 1551 & 21 & 1 & 20 & 20 & 0 & 20 & 155 & 7.8 \\
\hline & Combined & 49 & 3 & 46 & 42 & 4 & 38 & 192 & 8.3 \\
\hline \multirow[t]{3}{*}{11} & Deltex & 11 & 0 & 11 & 10 & 1 & 9 & 40 & 4.0 \\
\hline & TGR 1551 & 12 & 0 & 12 & 9 & 3 & 6 & 65 & 7.2 \\
\hline & Combined & 23 & 0 & 23 & 19 & 4 & 15 & 65 & 5.5 \\
\hline \multirow[t]{3}{*}{12} & Deltex & 11 & 0 & 11 & 10 & 1 & 9 & 87 & 8.7 \\
\hline & TGR 1551 & 10 & 1 & 9 & 8 & 1 & 7 & 68 & 8.5 \\
\hline & Combined & 21 & 1 & 20 & 18 & 2 & 16 & 87 & 8.6 \\
\hline \multirow{3}{*}{$\begin{array}{l}\text { Unassigned } \\
\text { markers }\end{array}$} & Deltex & 11 & 2 & & & & & & \\
\hline & TGR 1551 & 13 & 1 & & & & & & \\
\hline & Combined & 24 & 3 & & & & & & \\
\hline \multirow[t]{3}{*}{ Total } & Deltex & 192 & 12 & 171 & 148 & 22 & 126 & 1,182 & 8.0 \\
\hline & TGR 1551 & 158 & 8 & 138 & 127 & 11 & 116 & 1,163 & 9.2 \\
\hline & Combined & 350 & 20 & 309 & 275 & 33 & 242 & 1,394 & 8.5 \\
\hline
\end{tabular}

${ }^{\mathrm{z}}$ Markers significantly deviated from the expected 3:1 ratio $(P<0.05)$.

Arnas and Pitrat (1996) and Silberstein et al. (2003). However, differences in RAPD marker polymorphisms may be due to genetic distances between parents. Specifically, longer genetic distances between parental pairs ('Deltex' $\times$ TGR 1551, 'Vedrantais' $\times$ PI 161375, and PI $414723 \times$ 'Top Mark') are considered causal differences in marker polymorphisms versus those between parental pairs (MR1 × 'Yokneam' and PI 414723 $\times$ 'Dulce'). Baudracco-Arnas and Pitrat (1996) reported an even distribution of RAPDs throughout the melon genome. The equal distribution of RAPDs in the genome is confirmed here. This supports the application of RAPDs for C. melo linkage analysis.
One hundred ten markers from $218 \mathrm{~F}_{2}$ plants (BaudraccoArnas and Pitrat, 1996), 228 markers from 66 backcross plants (Wang et al., 1997), and 74 markers from $112 \mathrm{~F}_{2}$ plants (DaninPoleg et al., 2002) were distributed on 14 LGs of maps with 6 , 16 , and 7 unassigned markers. A total of 350 markers in $108 \mathrm{~F}_{2}$ plants were arranged into 12 LGs with 9 and 12 unassigned markers, which were consistent with the results of Oliver et al. (2001) and Perin et al. (2002b). They developed two maps having 12 LGs, with 21 and 5 unassigned markers, on the basis of 411 markers in $93 \mathrm{~F}_{2}$ plants and 465 markers in 163 recombinant inbred lines (RIL). Our 12 LGs correspond to the chromosome number of one complete set in melon (Dane, 

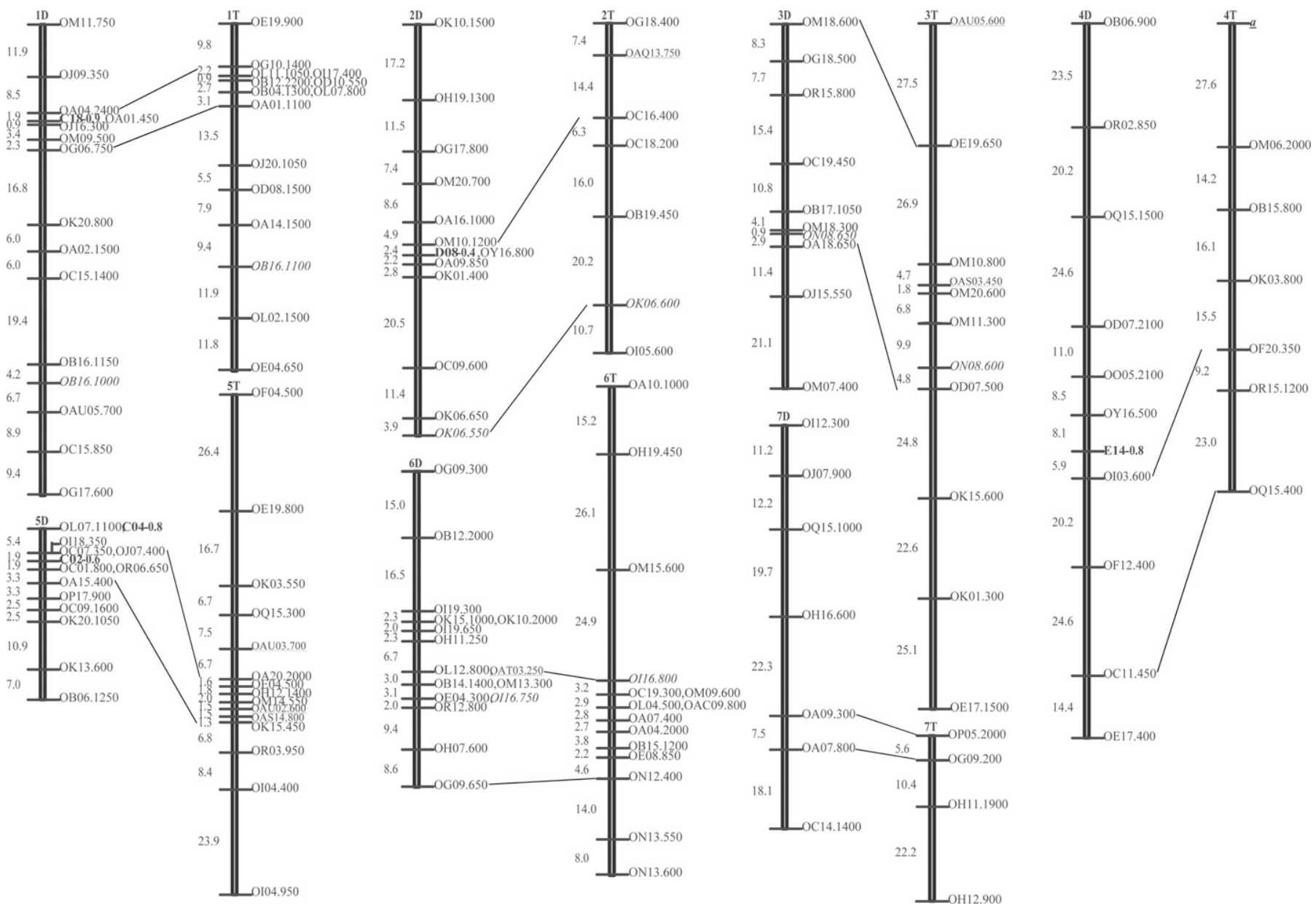

Fig. 1. (Continued on next page)

1991). Single or combined factors such as marker quantity, population size, and population structure may contribute to the differences in LG numbers.

Total genetic distances of published melon maps were reported to vary from 610 to $1942 \mathrm{cM}$ (Baudracco-Arnas and Pitrat, 1996; Danin-Poleg et al., 2002; Gonzalo et al., 2005; Oliver et al., 2001; Perin et al., 2002b; Silberstein et al., 2003; Wang et al., 1997; Zalapa et al., 2007). Ramachandran and Seshadri (1986) estimated the total melon genome distance of $2364 \mathrm{cM}$, while Staub and Meglic (1993) calculated the total genome distance of 2276 to $3250 \mathrm{cM}$. Total genetic distances of the published maps reflect $19 \%$ to $85 \%$ of the genome distance based on the estimated values of different analyses. Our 'Deltex' and TGR 1551 maps with total distances of 1182 and $1163 \mathrm{cM}$ cover $36 \%$ to $52 \%$ of the total melon genome. Nine and 12 unassigned markers suggest that the 'Deltex' and TGR 1551 maps do not fully represent the genome. Thus, current map distances can be improved through adding a greater number of genetic markers, allowing placement of the unassigned markers onto the maps.

A COMBINED LINKAGE MAP. Of 171 'Deltex'- and 138 TGR 1551-derived markers in two maps, we found six codominant RAPD marker pairs (Fig. 1). These codominant marker fragments cosegregated in the $F_{2}$ population. An example is a codominant marker pair OB16.1000 amplified from 'Deltex' and OB16.1100 amplified from TGR 1551. A goodness-of-fit to a 1:2:1 segregation ratio for each of the six markers was observed in $108 \mathrm{~F}_{2}$ plants $(P>0.05)$. The six marker pairs were already assigned on LGs of the 'Deltex' and TGR 1551 maps, and thus, we identified six homologous LG pairs, and arranged them as LGs 1, 2, 3, 6, 10, and 12 .

When selecting a codominant RAPD marker pair, four conditions were considered, as described by Perin et al. (2002b): 1) amplification of two markers from both parents by the same primer, 2) slight differences between the two markers in length, 3) complementary segregation of the markers within the population, and 4) no plant with double absence. Additionally, we searched each pairwise combination of 171 'Deltex'- and 138 TGR 1551-derived markers to detect codominant marker pairs based on two (3 and 4) of these criteria. These markers were used to connect the remaining six LGs. We selected 76 marker pairs having codominance, and noted a goodness-of-fit to a 1:2:1 ratio for each of the markers $(P>0.05)$ using the chisquare test. According to previous assignment of the 76 codominant markers, they were evenly distributed on all 12 LGs with an average of 6.3 markers per LG, and ranged from two on LG 7 to 13 on LG 10 (Fig. 1). We detected the remaining six homologous LG pairs based on these locations, and arranged them as LGs 4, 5, 7, 8, 9, and 11. Also, we confirmed locations of the original six codominant markers on six LGs due to their colinearity with other marker pairs on the LGs. Thus, a combined linkage map including 12 LGs with a total map 

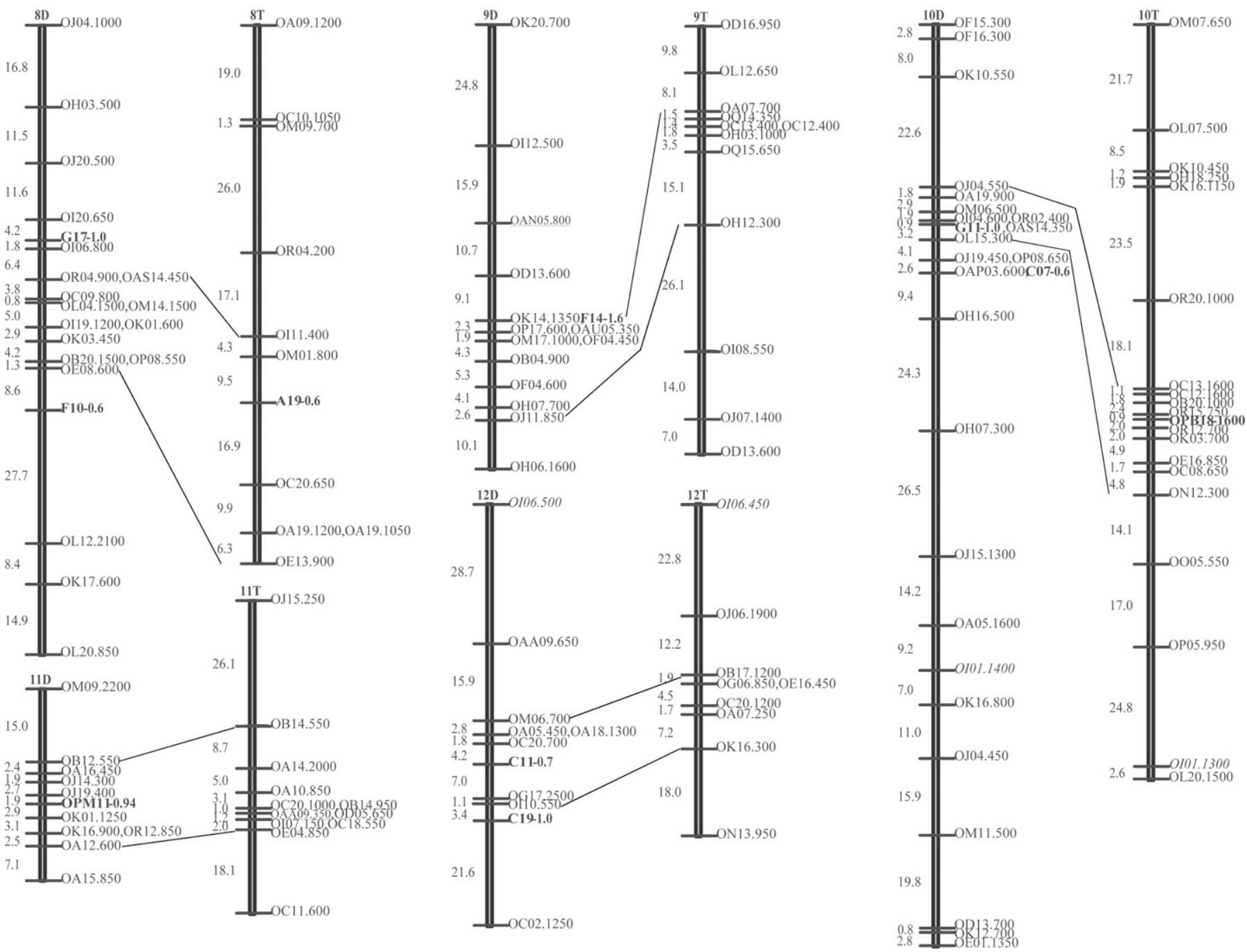

Fig. 1. (Continued from previous page) A melon linkage map including 350 'Deltex' (D)- and TGR 1551 (T)-derived randomly amplified polymorphic DNA (RAPD) markers constructed by means of an $F_{2}$ population of the 'Deltex' $\times$ TGR 1551 cross. The gene and marker names are given on the right and the length in centimorgan $(\mathrm{cM})$ is indicated on the left of each linkage group. Marker pairs having codominance are connected between each linkage group D and $\mathrm{T}$ pair by double lines. Six marker pairs in italic on linkage groups 1,2,3,6,10, and 12 are codominant RAPD markers. Sixteen markers in bold on linkage groups 1, 2, 4, 5, $8,9,10,11$, and 12 are common RAPD and andromonoecious $(a)$ markers originally derived from other published reference melon linkage maps (BaudraccoArnas and Pitrat, 1996; Oliver et al., 2001; Perin et al., 2002b; Pitrat, 1991; Silberstein et al., 2003). OAN05.800, underlined on linkage group 9, was linked to the $m s-3$ locus for male sterility at $21.5 \mathrm{cM}$ (Park et al., 2004b), and nine RAPD and $a$ markers underlined on linkage groups 2, 3, 4, 5, 6, and 11 were associated with muskmelon-derived quantitative trait loci for fruit quality traits (Sinclair et al., 2006).

distance of $1394 \mathrm{cM}$ was developed (Table 2). This map spans $43 \%$ to $61 \%$ of the total melon genome. These marker pairs can be used as coupling- and repulsion-phase markers for MAS in breeding as well as detecting major loci for traits of interest.

INTEGRATING CURRENT AND OTHER MAPS. Sixteen common RAPD and $a$ (Rosa, 1928) markers, including one originally published by Pitrat (1991), 13 from Baudracco-Arnas and Pitrat (1996), one from Oliver et al. (2001), and one from Silberstein et al. (2003) located on classical and molecular maps, were used to integrate our map into other reference maps (Table 3). Of the 16 markers, 13 were observed on nine LGs of the 'Deltex' map, while three were found on three LGs of the TGR 1551 map. Nine LGs having the common markers were identified in the combined map. The marker number per $\mathrm{LG}$ varied from one on LGs 1, 2, 9, and 11 to three on LGs 8 and 10. Eight LGs 1, 2, 4, $5,8,9,10$, and 12 of the combined map correspond to LGs G, 7 , D, E, 6, F, B, and A of the 'Vedrantais' $\times$ PI 161375 map
(Baudracco-Arnas and Pitrat, 1996), while LG 11 corresponds to LG G10 of the PI $161375 \times$ 'Piel de Sapo' map (Oliver et al., 2001). One LG 10 also corresponds to LG 6 of the PI $414723 \times$ 'Top Mark' map (Silberstein et al., 2003). Corresponding LG names of our map with the composite map (Perin et al., 2002b) are $1=\mathrm{I}, 2=\mathrm{XII}, 4=\mathrm{II}, 5=\mathrm{VIII}, 8=\mathrm{XI}, 9=\mathrm{VII}, 10=\mathrm{VI}, 11=$ $\mathrm{IV}$, and $12=\mathrm{X}$. Of our map distance of $1394 \mathrm{cM}, 1038 \mathrm{cM}$ (75\%) was joined with portions of the other published maps. However, the remaining three LGs were not integrated because no common markers were available. This map integration demonstrates the possibility for developing a consensus $C$. melo linkage map based on common markers, even though different parental genotypes and markers were involved.

The $a$ locus for andromonoecious, first reported by Rosa (1928), was located on LG 4 in the classical map (Pitrat, 1991). The $a$ locus was linked to zucchini yellow mosaic virus resistance Zym, powdery mildew resistance $P m-x$, and halo 
Table 3. Locations and sources of common RAPD markers, andromonoecious $(a)$, and male-sterile ( $m s-3)$ on linkage groups of the current map and other published reference melon maps.

\begin{tabular}{|c|c|c|c|c|c|c|c|}
\hline \multirow[b]{2}{*}{$\begin{array}{l}\text { Common } \\
\text { markers }^{2}\end{array}$} & \multicolumn{7}{|c|}{ Linkage groups of classical and molecular melon maps } \\
\hline & $\begin{array}{c}\text { Current } \\
\text { map }\end{array}$ & $\begin{array}{l}\text { Pitrat } \\
(1991)^{\mathrm{y}}\end{array}$ & $\begin{array}{l}\text { Baudracco-Arnas } \\
\text { and Pitrat }(1996)^{\mathrm{x}}\end{array}$ & $\begin{array}{c}\text { Oliver et al. } \\
(2001)^{\mathrm{w}}\end{array}$ & $\begin{array}{l}\text { Perin et al. } \\
(2002 b)^{v}\end{array}$ & $\begin{array}{c}\text { Silberstein et al. } \\
(2003)^{\mathrm{u}}\end{array}$ & $\begin{array}{c}\text { Park et al. } \\
(2004 b)^{t}\end{array}$ \\
\hline$\overline{\mathrm{C} 18-0.9}$ & 1D & & $\mathrm{G}$ & & $\mathrm{I}$ & & \\
\hline D08-0.4 & $2 \mathrm{D}$ & & 7 & & XII & & \\
\hline E14-0.8 & 4D & & $\mathrm{D}$ & & II & & \\
\hline$a$ & $4 \mathrm{~T}$ & 4 & & & II & 2 & \\
\hline $\mathrm{C} 04-0.8$ & $5 \mathrm{D}$ & & $\mathrm{E}$ & & VIII & & \\
\hline $\mathrm{C} 02-0.6$ & $5 \mathrm{D}$ & & E & & VIII & & \\
\hline G17-1.0 & $8 \mathrm{D}$ & & 6 & & XI & & \\
\hline F10-0.6 & $8 \mathrm{D}$ & & 6 & & XI & & \\
\hline A19-0.6 & $8 \mathrm{~T}$ & & 6 & & $\mathrm{XI}$ & & \\
\hline F14-1.6 & 9D & & $\mathrm{F}$ & & VII & & \\
\hline$m s-3$ & 9D & 10 & & & VII & & MT \\
\hline G11-1.0 & $10 \mathrm{D}$ & & B & & VI & & \\
\hline $\mathrm{C} 07-0.6$ & 10D & & B & & VI & & \\
\hline OPB18-1600 & $10 \mathrm{~T}$ & & & & VI & 6 & \\
\hline OPM11-0.94 & $11 \mathrm{D}$ & & & G10 & IV & & \\
\hline C11-0.7 & $12 \mathrm{D}$ & & A & & $\mathrm{X}$ & & \\
\hline C19-1.0 & $12 \mathrm{D}$ & & A & & $\mathrm{X}$ & & \\
\hline
\end{tabular}

${ }^{\mathrm{z}}$ Markers were commonly located on at least three different melon maps. The $a$ and $m s-3$ genes were discovered originally by Rosa (1928) and McCreight and Elmstrom (1984), respectively.

${ }^{\mathrm{y}} \mathrm{A}$ classical linkage map.

${ }^{\mathrm{x}} \mathrm{A}$ molecular map developed using $218 \mathrm{~F}_{2}$ plants from the 'Vedrantais' $\times$ PI 161375 cross.

wA molecular map developed using $93 \mathrm{~F}_{2}$ plants from the PI $161375 \times$ 'Piel de Sapo' cross.

vThe current melon consensus map developed using 163 recombinant inbred lines from the 'Vedrantais' $\times$ PI 161375 cross and 63 recombinant inbred lines from the 'Vedrantais' $\times$ PI 414723 cross.

"A molecular map developed using $113 \mathrm{~F}_{2}$ plants from the PI $414723 \times$ 'Top Mark' cross.

${ }^{t} \mathrm{~A}$ linkage group including $m s-3$ and OAN05.800 developed using the ms-3 $\times$ 'TAM Dulce' cross.

cotyledons $h$ on the LG. The $a$ marker was linked to QTL on LG II of the 'Vedrantais' $\times$ PI 414723 map, accounting for $47 \%$ of the fruit length variation (Perin et al., 2002a). Sinclair et al. (2006) reported an association of the $a$ locus with TSS or sucrose in a 'Dulce' $\times$ TGR 1551 cross. Pitrat (2005-2006) connected five LGs-LG 4 (Pitrat, 1991), LG D (Baudracco-Arnas and Pitrat, 1996), LG 8 (Oliver et al., 2001), LG II (Perin et al., 2002b), and LG IV (Danin-Poleg et al., 2002) in published maps using common phenotypic markers, including the $a$ locus. Silberstein et al. (2003) also mapped the $a$ locus on LG 2. We placed the $a$ marker on LG 4 (Fig. 1). Thus, LG 4 corresponds to the six LGs, including 4, D, 8, II, IV, and 2 of the melon maps.

The presence or absence of three 'Deltex' (OA18.650, OAT03.250, and OA07.800) and TGR 1551 (OK15.600, OA07.400, and OG09.200) marker pairs differentially located on LGs 3, 6, and 7 was investigated in 'Vedrantais', PI 161375, and PI 414723. All 'Deltex' markers were present in 'Vedrantais', while all TGR 1551 markers were present in PI 161375, indicating a genomic similarity between 'Deltex' and 'Vedrantais' or between TGR 1551 and PI 161375. OA18.650 and OK15.600 on LG 3, and OA07.800 and OG09.200 on LG 7 were polymorphic between 'Vedrantais' and PI 161375. OK15.600, OAT03.250, OA07.400, and OA07.800 on the three LGs were polymorphic between 'Vedrantais' and PI 414723. Perin et al. (2002b) used these genotype pairs as parents to create two RIL populations from which the composite map was developed. This marker survey suggests that the remaining three LGs can be integrated into regions of the composite map.

LOCATION OF MS-3 FOR MALE STERILITY. McCreight and Elmstrom (1984) discovered the muskmelon male-sterile gene $m s-3$ and Pitrat (1991) placed this gene on LG 10 of the classical map. Subsequently, RAPD (OAM08.650 and OAN05.800) and SCAR (SOAM08.644) markers that displayed an amplified DNA fragment in the male-sterile parent were identified to be linked to the $m s-3$ locus in an ms-3 $\times$ 'Dulce' cross (Park et al., 2004b). The RAPD OAM08.650 and SCAR SOAM08.644 markers were linked to the $m s-3$ locus at $2.1 \mathrm{cM}$, while the RAPD OAN05.800 marker was linked to the locus at $21.5 \mathrm{cM}$. However, we found only the OAN05.800 marker polymorphic between our parents. We noted a 3:1 ratio for band presence to band absence for the marker. The OAN05.800 marker linked to the $m s-3$ locus was assigned on LG 9 (Fig. 1 and Table 3). This LG 9 corresponds to LG F (Baudracco-Arnas and Pitrat, 1996), LG 3 (Oliver et al., 2001), LG VII (Perin et al., 2002b), LG VI (Danin-Poleg et al., 2002), and LG 16 (Silberstein et al., 2003) of molecular maps, as well as LG 10 (Pitrat, 1991) of the classical map. Thus, we extended the consensus $C$. melo map by connecting between LG 10 of the classical map and LG VII of the composite map. This is the first report on mapping of the $m s-3$ locus in the composite melon map.

MAPPING OF QTL FOR SUCROSE. Nine RAPD markers were identified to be associated with QTL for sucrose in the high sucrose 'Dulce' $\times$ low sucrose TGR 1551 cross (Sinclair et al., 2006). Five RAPD markers were polymorphic between 'Deltex' and TGR 1551 and a 3:1 goodness-of-fit ratio for each of the five markers was observed in the population. We already assigned these markers (OAQ13.750, OAS03.450, OAU05.600, OAT03.250, and OAA09.350) on LGs 2, 3, 3, 6, and 11 (Fig. 1 and Table 4). Even if OAS03.450 and OAU05.600 were located on LG 3, the distance between the markers was $59.1 \mathrm{cM}$, 
supporting the result of Sinclair et al. (2006) that the RAPD markers for sucrose were unlinked. They found a linkage of the $a$ locus on LG 4 with OAP03.800 at $26.4 \mathrm{cM}$. Three of these markers were also confirmed in different populations and environments to be associated with QTL for sucrose. These six markers on five LGs accounted for $44 \%$ of the total sucrose variation. Thus, we mapped six QTL for sucrose.

Common QTL For SweEtness. Of the six RAPD markers associated with QTL for sucrose, three on LGs 3, 4, and 6 and four on LGs 2, 3, 6, and 11 were also observed to be associated with QTL for TSS and RSTS, respectively (Table 4). These results suggest that three sugar traits are controlled by the same QTL in this population. These three and four marker combinations explained $20 \%$ and $31 \%$ of the total variation for the traits, respectively. We found two and three of the sucrose QTL to be associated with glucose and fructose, respectively, while we noted four of the QTL to be associated with ratios of glucose and fructose to total sugars as well.

MAPPING OF QTL FOR ASCORBIC ACID. Sinclair et al. (2006) reported an association of four TGR 1551 RAPD markers with a single QTL affecting ascorbic acid in the high ascorbic acid 'Dulce' $\times$ low ascorbic acid TGR 1551 cross. The four individual markers accounted for $7 \%$ to $9 \%$ of the ascorbic acid variation. OAS14.800, OAU02.600, and OAU03.700 segregated in our population, whereas OAW10.400 was nonscored. We observed a 3:1 goodness-of-fit ratio for each of the three markers $(P>0.05)$. All three markers for ascorbic acid previously confirmed in different crosses and environments (Sinclair et al., 2006) were located on LG 5 and linked within
$15.1 \mathrm{cM}$ (Table 4). Thus, we detected a QTL for the important antioxidant, ascorbic acid, on LG 5 (Fig. 1).

Additional map Utilization. Fruits of 'Deltex' have high total sugars $\left(68.4 \mathrm{mg} \cdot \mathrm{g}^{-1}\right)$ and sucrose $\left(37.5 \mathrm{mg} \cdot \mathrm{g}^{-1}\right)$. In contrast, those of TGR 1551 possess low total sugars (28.7 $\left.\mathrm{mg} \cdot \mathrm{g}^{-1}\right)$ and sucrose $\left(0.0 \mathrm{mg} \cdot \mathrm{g}^{-1}\right)$ (Table 1$)$. Our map should prove helpful in identifying QTL for these sugar traits. Also, markers should be screened for linkage to QTL impacting high ascorbic acid in the high $\times$ low ascorbic acid cross. Subsequently, it will be beneficial to determine the relationships of the 'Deltex' and 'Dulce'-derived QTL to discern common and different QTL for sucrose or ascorbic acid. Due to clear differences for fruit and seed size between the parents, QTL for fruit size and shape, flesh size and diameter, seed cavity size and diameter, and seed size and quantity could be placed on the map. This map should also prove useful in detecting loci for resistance to CYSDV, Fusarium wilt, powdery mildew, and downy mildew.

\section{Conclusions}

Our genetic linkage map using an $\mathrm{F}_{2}$ population of the 'Deltex' $\times$ TGR 1551 cross included 12 LGs with a total map distance of $1394 \mathrm{cM}$ and covered $43 \%$ to $61 \%$ of the total melon genome. Nine LGs of the map were integrated into those of the existing $C$. melo map. The $m s-3$ locus for male sterility was positioned on LG 9. We mapped six QTL for sucrose on LGs 2, 3, 4, 6, and 11. Three of the six QTL for sucrose were associated with TSS, while four of the QTL were associated with RSTS. A single QTL for

Table 4. Mapping of 10 RAPD markers and andromonoecious $(a)$ on six linkage groups (LG) of the combined melon linkage map associated with 'Dulce'-derived quantitative trait loci for eight fruit quality traits including total soluble solids (TSS), three sugars, ratio of sucrose to total sugars (RSTS), ratio of glucose to total sugars (RGTS), ratio of fructose to total sugars (RFTS), and ascorbic acid (AA) in $105 \mathrm{~F}_{2}$ plants of the 'TAM Dulce' $\times$ TGR $1551(\mathrm{TT})$ cross and $64 \mathrm{~F}_{2}$ plants of the 'Deltex' $\times$ TGR 1551 (DT) cross.

\begin{tabular}{|c|c|c|c|c|c|c|c|c|c|c|c|}
\hline \multirow[b]{2}{*}{ Marker $^{z}$} & \multirow[b]{2}{*}{ LG } & \multirow[b]{2}{*}{ Cross } & \multirow[b]{2}{*}{ Environment } & \multicolumn{8}{|c|}{ Fruit quality traits } \\
\hline & & & & TSS & Sucrose & Glucose & Fructose & RSTS & RGTS & RFTS & $\overline{\mathrm{AA}}$ \\
\hline \multirow[t]{2}{*}{ OAQ13.750 } & $2 \mathrm{~T}$ & TT & Greenhouse & & $* *$ & & & $* *$ & $* *$ & & \\
\hline & & DT & Field & & & & & & & & \\
\hline \multirow[t]{2}{*}{ OAS03.450 } & $3 \mathrm{~T}$ & $\mathrm{TT}$ & Greenhouse & $* * *$ & $* *$ & $* *$ & $*$ & & & $* *$ & \\
\hline & & DT & Field & $* * *$ & & $*$ & $* *$ & & & & \\
\hline \multirow[t]{2}{*}{ OAU05.600 } & $3 \mathrm{~T}$ & TT & Greenhouse & & $* * *$ & & & $* *$ & $*$ & $*$ & \\
\hline & & DT & Field & & $* *$ & & & $*$ & & $* * *$ & \\
\hline \multirow[t]{2}{*}{$a$} & $4 \mathrm{~T}$ & $\mathrm{TT}$ & Greenhouse & $*$ & $*$ & & & & & & \\
\hline & & DT & Field & $* * *$ & $* * *$ & & & & & & \\
\hline \multirow[t]{2}{*}{ OAP03.800 } & $4 \mathrm{~T}$ & $\mathrm{TT}$ & Greenhouse & $* *$ & $* *$ & $* *$ & $*$ & & & $*$ & \\
\hline & & DT & Field & & & & & & & & \\
\hline \multirow[t]{2}{*}{ OAS14.800 } & $5 \mathrm{~T}$ & $\mathrm{TT}$ & Greenhouse & & & & & & & & $* *$ \\
\hline & & DT & Field & & & & & & & & $* *$ \\
\hline \multirow[t]{2}{*}{ OAU02.600 } & $5 \mathrm{~T}$ & $\mathrm{TT}$ & Greenhouse & & & & & & & & $* *$ \\
\hline & & DT & Field & & & & & & & & $*$ \\
\hline \multirow[t]{2}{*}{ OAU03.700 } & $5 \mathrm{~T}$ & $\mathrm{TT}$ & Greenhouse & & & & & & & & $* * *$ \\
\hline & & DT & Field & & & & & & & & $* *$ \\
\hline \multirow[t]{2}{*}{ OAT03.250 } & $6 \mathrm{D}$ & TT & Greenhouse & $*$ & $*$ & & $* *$ & $*$ & $* * *$ & & $*$ \\
\hline & & DT & Field & & & & & & & & \\
\hline \multirow[t]{2}{*}{ OAA09.350 } & $11 \mathrm{~T}$ & $\mathrm{TT}$ & Greenhouse & & $* * *$ & & & $* * *$ & $*$ & $* * *$ & \\
\hline & & DT & Field & & $* *$ & & & $* * *$ & $* * *$ & $* * *$ & \\
\hline \multirow[t]{2}{*}{ Total $R^{2}(\%)$} & & $\mathrm{TT}$ & Greenhouse & 20 & 44 & 12 & 10 & 31 & 24 & 27 & 13 \\
\hline & & DT & Field & 35 & 29 & 4 & 6 & 16 & 11 & 23 & 6 \\
\hline
\end{tabular}

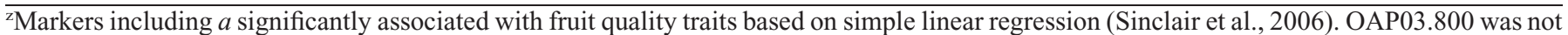
included in the map but linked to the $a$ locus on LG 4 at $26.4 \mathrm{cM}$.

$*, * *, * *$ Significant at $P \leq 0.05,0.01$, or 0.001 , respectively. 
ascorbic acid was placed on LG 5. This map should prove helpful in efforts to identify QTL for disease resistance, as well as melon fruit sweetness, quality, and size traits.

\section{Literature Cited}

Adams, C.F. and M. Richardson. 1981. Nutritive value of foods. U.S. Dept. Agr. Home and Garden Bul. 72.

Alvarez, J.M., R. Gonz lez-Torres, C. Mallor, and M.L. GûmezGuillamûn. 2005. Potential sources of resistance to fusarium wilt and powdery mildew in melons. HortScience 40:1657-1660.

Arumuganathan, K. and E.D. Earle. 1991. Nuclear DNA content of some important plant species. Plant Mol. Biol. Rpt. 9:211-215.

Baudracco-Arnas, S. and M. Pitrat. 1996. A genetic map of melon (Cucumis melo L.) with RFLP, RAPD, isozyme, disease resistance and morphological markers. Theor. Appl. Genet. 93:57-64.

Dane, F. 1991. Cytogenetics of the genus Cucumis, p. 201-214. In: T. Tsuchiya and P.K. Gupta (eds.). Chromosome engineering in plants: Genetics, breeding, evolution, Part B. Elsevier, Amsterdam, The Netherlands.

Danin-Poleg, Y., N. Reis, G. Tzuri, and N. Katzir. 2001. Development and characterization of microsatellite markers in Cucumis. Theor. Appl. Genet. 102:61-72.

Danin-Poleg, Y., N. Reis, S. Baudracco-Arnas, M. Pitrat, J.E. Staub, M. Oliver, P. Arús, C.M. de Vicente, and N. Katzir. 2000. Simple sequence repeats in Cucumis mapping and map merging. Genome 43:963-974.

Danin-Poleg, Y., Y. Tadmor, G. Tzuri, N. Reis, J. Hirschberg, and N. Katzir. 2002. Construction of a genetic map of melon with molecular markers and horticultural traits, and localization of genes associated with ZYMV resistance. Euphytica 125:373-384.

Gonzalo, M.J., M. Oliver, J. Garcia-Mas, A. Monfort, R. DolcetSanjuan, N. Katzir, P. Arús, and A.J. Monforte. 2005. Simplesequence repeat markers used in merging linkage maps of melon (Cucumis melo L.). Theor. Appl. Genet. 110:802-811.

Jahn, M., H.M. Munger, and J.D. McCreight. 2002. Breeding cucurbit crops for powdery mildew resistance, p. 239-248. In: R.R. Bélanger, W.R. Bushnell, A.J. Dik, and T.L.W. Carver (eds.). The powdery mildews: A comprehensive treatise. APS Press, St. Paul, MN.

Kosambi, D.D. 1944. The estimation of map distances from recombination values. Ann. Eugen. 12:172-175.

Lander, E.S., P. Green, J. Abrahamson, A. Barlow, M.J. Daly, S.E. Lincoln, and L. Newburg. 1987. MAPMAKER: An interactive computer package for constructing primary genetic linkage maps with experimental and natural populations. Genomics 1:174-181.

Lester, G. 1997. Melon (Cucumis melo L.) fruit nutritional quality and health functionality. HortTechnology 7:222-227.

Lester, G.E. and K.C. Shellie. 1992. Postharvest sensory and physicochemical attributes of honey dew melon fruits. HortScience 27:1012-1014.

Lopez-Sese, A.I. and M.L. Gomez-Guillamon. 2000. Resistance to cucurbit yellowing stunting disorder virus (CYSDV) in Cucumis melo L. HortScience 35:110-113.

Martyn, R.D. and M.E. Miller. 1996. Monosporascus root rot/vine decline: An emerging disease of melons worldwide. Plant Dis. 80:716-725.

McCreight, J.D. and G.W. Elmstrom. 1984. A third muskmelon malesterile gene. HortScience 19:268-270.

Monforte, A.J., M. Oliver, M.J. Gonzalo, J.M. Alvarez, R. DolcetSanjuan, and P. Arus. 2004. Identification of quantitative trait loci involved in fruit quality traits in melon (Cucumis melo L.). Theor. Appl. Genet. 108:750-758.

Oliver, M., J. Garcia-Mas, M. Cardús, N. Pueyo, A.I. López-Sesé, M. Arroyo, H. Gómez-Paniagua, P. Arús, and M.C. de Vicente. 2001. Construction of a reference linkage map for melon. Genome 44:836845.

Park, S.O., D.P. Coyne, J.R. Steadman, K.M. Crosby, and M.A. Brick. 2004a. RAPD and SCAR markers linked to the Ur-6 Andean gene controlling specific rust resistance in common bean. Crop Sci. 44:1799-1807.

Park, S.O., D.P. Coyne, N. Mutlu, G. Jung, and J.R. Steadman. 1999. Confirmation of molecular markers and flower color associated with QTL for resistance to common bacterial blight in common beans. J. Amer. Soc. Hort. Sci. 124:519-526.

Park, S.O., K.M. Crosby, and K.S. Yoo. 2006. Quantitative trait loci affecting ascorbic acid in melon. 27th Intl. Hort. Congr., p. 234. (Abstr.).

Park, S.O., K.M. Crosby, R.F. Huang, and T.E. Mirkov. 2004b. Identification and confirmation of RAPD and SCAR markers linked to the $m s-3$ gene controlling male sterility in melon (Cucumis melo L.). J. Amer. Soc. Hort. Sci. 129:819-825.

Park, S.O., Z.H. Kim, and K.M. Crosby. 2007a. Mapping of QTL controlling fruit size and shape traits in ananas melon. HortScience 42:962. (Abstr.).

Park, S.O., Z.H. Kim, and K.M. Crosby. 2007b. Mapping of QTL for the number of seeds, total seed weight, and single seed weight in melon. HortScience 42:961. (Abstr.).

Park, S.O., Z.H. Kim, K.S. Yoo, and K.M. Crosby. 2007c. Mapping of QTL affecting sugars in ananas melon. HortScience 42:962. (Abstr.).

Perin, C., L.S. Hagen, N. Giovinazzo, D. Besombes, C. Dogimont, and M. Pitrat. 2002a. Genetic control of fruit shape acts prior to anthesis in melon (Cucumis melo L.). Mol. Genet. Genomics 266:933941.

Perin, C., L.S. Hagen, V. de Conto, N. Katzir, Y. Danin-Poleg, V. Portnoy, S. Baudracco-Arnas, J. Chadoeuf, C. Dogimont, and M. Pitrat. 2002b. A reference map of Cucumis melo based on two recombinant inbred line populations. Theor. Appl. Genet. 104:10171034.

Perin, C., M. Gomez-Jimenez, L. Hagen, C. Dogimont, J. Pech, A. Latche, M. Pitrat, and J. Lelievre. 2002c. Molecular and genetic characterization of a non-climacteric phenotype in melon reveals two loci conferring altered ethylene response in fruit. Plant Physiol. 129:300-309.

Pitrat, M. 1991. Linkage groups in Cucumis melo L. J. Hered. 82:406411.

Pitrat, M. 2005-2006. 2006 gene list for melon. Cucurbit Genet. Coop. Rpt. 28-29:142-163.

Pitrat, M., P. Hanelt, and K. Hammer. 2000. Some comments on infraspecific classification of cultivars of melon. Acta Hort. 510:2936.

Ramachandran, C. and V.S. Seshadri. 1986. Cytological analysis of the genome of cucumber (Cucumis sativus L.) and muskmelon (Cucumis melo L.). Zeitschrift fuer Pflanzenzuechtung 96:25-38.

Richter, H. 2000. Fresh produce guide: Nutrition, selection, preparation, storage, handling, cooking tips. Try-Foods Intl. Inc., Apopka, FL.

Rosa, J.T. 1928. The inheritance of flower types in Cucumis and Citrullus. Hilgardia 3:233-250.

Silberstein, L., I. Kovalski, Y. Brotman, C. Perin, C. Dogimont, M. Pitrat, J. Klingler, G. Thompson, V. Portnoy, N. Katzir, and R. PerlTreves. 2003. Linkage map of Cucumis melo including phenotypic traits and sequence-characterized genes. Genome 46:761-773.

Sinclair, J.W., S.O. Park, G.E. Lester, K.S. Yoo, and K.M. Crosby. 2006. Identification and confirmation of RAPD markers and andromonoecious associated with quantitative trait loci for sugars in melon. J. Amer. Soc. Hort. Sci. 131:360-371.

Skroch, P.W. and J. Nienhuis. 1995. Qualitative and quantitative characterization of RAPD variation among snap bean genotypes. Theor. Appl. Genet. 91:1078-1085.

Staub, J.E. and V. Meglic. 1993. Molecular genetic markers and their relevance for cultivar discrimination: A case study in cucumber. HortTechnology 3:291-299.

Staub, J.E., J. Box, V. Meglic, T.F. Horejsi, and J.D. McCreight. 1997. Comparison of isozyme and random amplified polymorphic DNA data for determining intraspecific variation in Cucumis. Genet. Resources Crop Evol. 44:257-269. 
Staub, J.E., V. Meglic, and J.D. McCreight. 1998. Inheritance and linkage relationships of melon (Cucumis melo L.) isozymes. J. Amer. Soc. Hort. Sci. 123:264-272.

U.S. Government Printing Office. 1990. Code of Federal regulations 7C-FR979.304. U.S. Government Printing Office, Washington, DC.

Wang, Y.H., C.E. Thomas, and R.A. Dean. 1997. A genetic map of melon (Cucumis melo L.) based on amplified fragment length polymorphism (AFLP) markers. Theor. Appl. Genet. 95:791-798.
Williams, J., A. Kubelik, K. Livak, J. Rafalksi, and S. Tingey. 1990. DNA polymorphisms amplified by arbitrary primers are useful as genetic markers. Nucleic Acids Res. 18:6531-6535.

Zalapa, J.E., J.E. Staub, J.D. McCreight, S.M. Chung, and H. Cuevas. 2007. Detection of QTL for yield-related traits using recombinant inbred lines derived from exotic and elite U.S. western shipping melon germplasm. Theor. Appl. Genet. 114:11851201. 